\title{
THORACIC DISC HERNIATION: SURGICAL DECOMPRESSION BY POSTERIOR APPROACH A LA CARTE
}

\author{
HÉRNIA DE DISCO TORÁCICO: DESCOMPRESSÃO CIRÚRGICA POR VIA POSTERIOR \\ A $L A C A R T E$
}

\author{
HERNIA DE DISCO TORÁCICO: DESCOMPRESIÓN QUIRÚRGICA POR VIÁA POSTERIOR \\ A LA CARTA
}

Murilo Tavares Daher 1,2, Pedro Felisbino Júnior1, Adriano Passáglia Esperidião1, Brenda Cristina Ribeiro Araújo1, André Luiz Passos Cardoso², Wilson EloY PIMENTA JúNIOR², SÉrgio DaHeR ${ }^{1}$

1. Centro de Reabilitação e Readaptação Dr. Henrique Santillo (CRER) [Dr. Henrique Santillo Center for Rehabilitation and Readaptation], Spine Group, Goiânia, GO, Brazil. 2. Universidade Federal de Goiás, Department of Orthopedics and Traumatology, GO, Brazil.

\begin{abstract}
Objectives: To present the clinical and radiographic results of patients with thoracic disc herniation treated by the posterior approach, according to location and type of hernia (à la carte). Methods: We evaluated thirteen patients (14 hernias) treated by the posterior approach. Eight (61.5\%) patients were male and the mean age was 53 years (34-81). Clinical evaluation was performed by the Frankel and JOA modified scales. All the patients underwent the posterior approach, which was performed by facetectomy, transpedicular approach, transpedicular + partial body resection, costotransversectomy or costotransversectomy + reconstruction with CAGE. Results: The mean follow-up was 2 years and 6 months (11-77 months). Of the 14 operated hernias, six (43\%) were lateral, 2 (14\%) paramedian, and 6 (43\%) central. Seven were soft (50\%) and seven were calcified. The transfacet approach was carried out in 5 cases (36\%), transpedicular in 1 case $(7 \%)$, transpedicular + partial body resection in 4 (29\%), costotransversectomy in $3(21 \%)$, and costotransversectomy + CAGE in one case (7\%). The majority of patients with lateral hernia (5/6) were subjected to transfacet decompression and in cases of central and paramedian hernias, all patients underwent decompression, which is more extensive. Conclusions: The posterior approach is safe and effective, and the best approach must be chosen based on location and type of the herniation and the surgeon's experience.
\end{abstract}

Keywords: Spine; Intervertebral disc displacement; Spondylosis; Evaluation of results of therapeutic interventions; Spinal cord compression.

\section{RESUMO}

Objetivos: Apresentar os resultados clínicos e radiográficos de pacientes com hérnia de disco torácico tratados pela via posterior com uma abordagem que variou de acordo com a localização e o tipo da hérnia (descompressão à la carte). Métodos: Foram avaliados treze pacientes (quatorze hérnias) tratados pela via posterior. Oito (61,5\%) pacientes do sexo masculino e média de idade de 53 anos (34 a 81$)$. A avaliação clínica foi realizada através de escala de Frankel e JOA modificada. Todos os pacientes foram submetidos à abordagem posterior, que foi realizada por facetectomia, via transpedicular, via transpedicular + ressecção parcial do corpo, costotransversectomia ou costotransversectomia + reconstrução com CAGE. Resultados: O tempo médio de seguimento foi de 2 anos e 6 meses (11 a 77 meses). Das 14 hérnias operadas, seis (43\%) eram laterais, duas (14\%) centrolaterais e seis (43\%) centrais. Sete eram moles (50\%) e sete calcificadas. A abordagem transfacetária foi realizada em cinco casos (36\%), transpedicular em um caso (7\%), transpedicular + ressecção parcial do corpo em quatro casos (29\%), costotransversectomia em três casos (21\%) e costotransversectomia + CAGE em um caso (7\%). A grande maioria dos pacientes com hérnias laterais foi submetida a descompressão transfacetária (5/6) e nos casos de hérnia central ou centrolateral todos foram submetidos a descompressão mais ampla. Conclusões: A via posterior é segura e eficaz no tratamento da maioria dos casos de hérnia de disco torácico, devendo ser escolhida a melhor abordagem de acordo com a localização da hérnia, do seu tipo e da experiência do cirurgião.

Descritores: Coluna vertebral; Deslocamento do disco intervertebral; Espondilose; Avaliação de resultado de intervenções terapêuticas; Compressão da medula espinal.

\section{RESUMEN}

Objetivos: Presentar los resultados clínicos y radiográficos de pacientes con hernia de disco torácico tratada por la vía posterior con un abordaje que varió de acuerdo con la ubicación y tipo de hernia (descompresión a la carta). Métodos: Fueron evaluados trece pacientes (catorce hernias) tratados por vía posterior. Ocho (61,5\%) pacientes eran hombres y la edad media de 53 años (34-81). La evaluación clínica se realizó mediante las escalas de Frankel y JOA modificada. Todos los pacientes fueron sometidos a abordaje posterior, que fue realizado por facetectomía, vía transpedicular, transpedicular + resección parcial del cuerpo, costotransversectomía o costotransversectomía + reconstrucción con CAGE. Resultados: La media de seguimiento fue de 2 años y 6 meses (11-77 meses). De las 14 hernias operadas, seis (43\%) eran laterales, dos (14\%) centro-laterales y seis (43\%) centrales. Siete eran moles y siete calcificadas. El abordaje transfacetário se llevó a cabo en cinco casos (36\%), el transpedicular en un caso (7\%), transpedicular + resección parcial del cuerpo en cuatro casos (29\%) costotransversectomía en tres casos (21\%) y costotransversectomía + CAGE en un caso (7\%). La gran mayoría (5/6) de los pacientes con hernias laterales se sometió a la descompresión transfacetária y en casos de hernia central o centro-lateral todos se sometieron a descompresión más extensa. Conclusiones: El abordaje posterior es seguro y eficaz en el tratamiento de la mayoría de los casos de hernia de disco torácico, y el mejor abordaje debe ser elegido de acuerdo con la ubicación y el tipo de la hernia y la experiencia del cirujano.

Descriptores: Columna vertebral; Desplazamiento del disco intervertebral; Espondilosis; Evaluación de resultados de intervenciones terapéuticas; Compresión de la médula espinal. 


\section{INTRODUCTION}

The incidence of symptomatic thoracic disc herniation (TDH) is one to a million in the general population ${ }^{1}$ and it is estimated that the procedures to treat this pathology represent only $0.15 \%$ to $4 \%$ of all surgeries for intervertebral disc disorders. ${ }^{2}$ They affect mainly females, and the peak incidence is at between 40 and 50 years of age. ${ }^{3}$

Despite their low prevalence, treatment is highly controversial, and a wide variety of procedures has been described for the treatment of these lesions, which have a challenging location. ${ }^{1}$ These procedures can be divided into two main groups: anterior approaches (thoracotomy, transsternal, retropleural and thoracoscopy) and posterior or posterior-lateral approaches (transfacet, transpedicular, costotransversectomy and lateral extracavitary)..$^{1,4}$

In all areas of the vertebral spine, use of the anterior approaches has been decreasing, while the posterior approaches have increased in popularity. ${ }^{5,6}$ This has become a clear trend in modern spine surgery, and many recently-qualified surgeons have had difficulty completing an adequate learning curve for the anterior approaches. In this context, various studies have been conducted demonstrating treatment of thoracic disc hernias by the posterior approach, ${ }^{7-10}$ but the majority present treatment of all cases, regardless of their location or the presence or absence of calcification, using the same technique..$^{7-9}$

The aim of our study is to demonstrate the treatment of a series of patients with thoracic disc herniation treated by the posterior approach, with individualized bone decompression for each type of hernia, enabling decompression of the neurological structures without manipulation of the dura-mater. We have termed this type of decompression à la carte, in an analogy with the peritalar release technique used in the treatment of congenital clubfoot. ${ }^{11}$

\section{METHODS}

This is a retrospective case series. After obtaining approval from the Institutional Review Board (IRB) (opinion number 1,255,060) the patient records and imaging exams were collected for 13 consecutive patients submitted to surgical treatment of TDH, by the same surgeon, at a single center, in the period from January 2009 to December 2014.

There were eight male patients (61.5\%) patients and five female patients (38.5\%) with an average age of 53 years (34 to 81). The level most affected was T11-T12, with four cases (29\%), followed by T8-T9 with three cases (21\%), T12-L1 and T7-T8 with two cases (14\%) and T10-T11, T4-T5 and T3-T4 with one case (7\%). All the patients presented hernia in only one level, except for one patient, who presented hernia in two levels (T3T4 and T4T5), making a total of 14 discs operated on.

The diagnostic was performed through magnetic resonance imaging in all patients, and where there was doubt as to the presence or absence of calcification, computed tomography was performed (7/13 patients). Seven patients presented calcification in the CT scan (hard hernia) and seven presented hypersignal of the weighted images in T2 in the MRI without signal of calcification in the CT scan (soft hernia).

The hernias were classified, according to their location in relation to the spinal cord, as central, central-lateral, and lateral. ${ }^{10}$ We considered hernias affecting only the spinal cord only as central, those affecting partially the spinal cord and the root as central-lateral, and those not affecting the spinal cord as lateral. We classified them in this way because we believe that the position of the hernia in relation to the spinal cord is one of the most important factors in the surgical planning. (Figure 1)

All 13 patients (14 hernias) were submitted to decompression and discectomy by the posterior approach with à la carte bone decompression (resection of the smallest amount of bone possible to approach the disc hernia without manipulating the vertebral spine). We divided this decompression into 5 stages, according to the amount of bone resected.

Stage 1 - transfacet decompression ${ }^{8,12,13}$ (sparing the pedicle): a median incision is made with subperiostal dissection and lateral exposure of the posterior vertebral elements, in standard form,

to access the disc. Using Curettes and Kerrinson's rongeurs, a laminectomy of this side is performed, resecting the entire joint facet (inferior portion of the superior facet and superior portion of the inferior facet). Thus, the disc fragments are resected, and with the aid of angled instruments (hooks), and anterior region of the dura-mater is accessed without manipulating the spinal cord.

Stage 2 - transpedicular decompression: ${ }^{7,14}$ after laminectomy and resection of the joint facet of the affected side, resection of the pedicle of the distal level is performed (in one case of a disc hernia at T11-T12, the pedicle of T12) using a high-rotation drill. After fully emptying the interior of the pedicle, its walls are removed using Love and Leksell rongeurs (punches). By this means, it is possible to increase its lateral tilt medially, and obtain a more medial view of the anterior region of the dura, without manipulating the neurological structures.

Stage 3 - transpedicular decompression associated with partial resection of the vertebral body: ${ }^{15}$ after laminectomy and resection of the facet and pedicle next to the hernia to be resected, the body and disc are destroyed using a high-rotation drill, enabling the more medially-located herniated disc to be pushed forwards (into the cavity created by the destruction of the vertebral body) using angled instruments (inverted curettes or bone compactors).

Stage 4 - costotransversectomy: ${ }^{10,16}$ after laminectomy, resection of the facet and pedicle, the periosteum is removed, resecting 3 to $5 \mathrm{~cm}$ of the proximal portion of the inferior rib, disarticulating it at the level of costovertebral and costotransversal joints. This gives the surgeon a better view, enabling him or her to work in the anterior region of the dura-mater without manipulating the neural structures. In these cases, part of the body and disc can also be destroyed using a high-rotation drill, always enabling the herniated disc to be manipulated in the opposite direction to the dura-mater (posterior to anterior). To perform a broader dissection and resection of part of the rib, the parietal pleura may be violated; this can be packed with collagen sponges, without requiring chest drainage. We advise, however, that postoperative control always be done, with chest $x$-rays.

Stage 5 - costotransversectomy and reconstruction with CAGE: after laminectomy, resection of the facet, pedicle, proximal portion of the rib and anterior portion of the vertebral body - particularly when this is bilateral, in cases of medial and highly

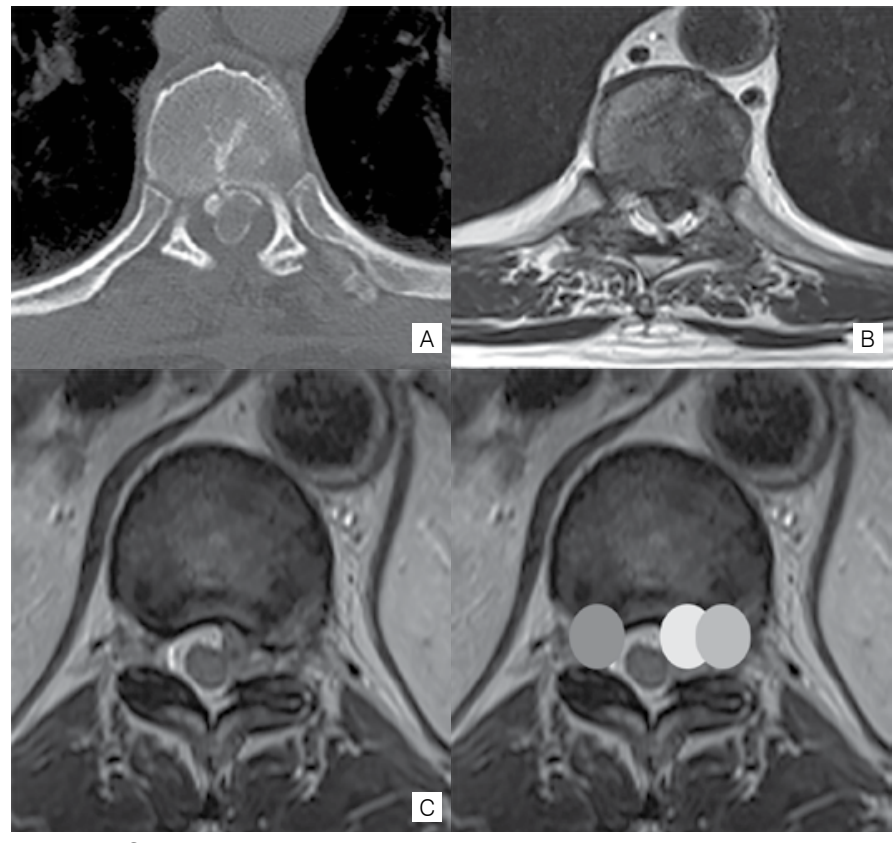

Figure 1. Classification of the hernia according to its position in relation to the spinal cord. A - axial section of CT showing a central, hard (calcified) hernia. $\mathrm{B}$ - Axial section of MRI showing central-lateral hernia/ $\mathrm{C}$ - axial section of MRI showing lateral, soft hernia (hypersignal of the images weighted in T2. 
calcified hernias - reconstruction of the anterior column may be necessary; this is generally done using a CAGE, which is inserted by the posterior-lateral approach.

In cases of transpedicular resections with partial resection of the vertebral body, costotransversectomy, and costotransversectomy with CAGE reconstruction (stages 3 to 5), a bilateral approach may be necessary, particularly in cases of central, calcified hernias, and in revision surgeries.

The clinical evaluation was performed based on the Franke $1{ }^{17}$ and JOA (Japanese Orthopaedic Association) scales adapted for thoracic myelopathy.$^{18}$ In the JOA scale for cervical myelopathy, the maximum score is 17 points. Excluding the items relating to evaluation of the upper limbs (motor function and sensitivity), we have a maximum score of 11. The recovery rate was calculated using the formula [(postoperative value - preoperative value)/(11 - preoperative value) $\times 100 \%]$ as suggested by Hirabayashi et al..$^{19}$ The recovery rate was classified in 5 types: excellent (75 to 100\%), good (50 to $74 \%$ ), reasonable (25 to $49 \%$ ), unchanged (0 to $24 \%$ ) and worse (less than $0 \%)^{20}$

The statistical evaluation was performed through the Student's $t$ test to compare the pre- and postoperative neurological evaluations. A level of significance of $p<0.05$ was considered [program PSS (Statistical Package for Social Sciences) version 13.0].

\section{RESULTS}

The demographic data of the patients are shown in Table 1. The mean follow-up time of the patients was two years and six months (11 to 77 months), with the exception of one patient who died six months after surgery and was not considered. This patient had comorbidities of morbid obesity, hypertension, diabetes, arrhythmia, and Chagas disease, and was paraparetic on admission to hospital (Frankel C). After surgery, when referred to the rehabilitation service, the patient refused to be admitted and was lost to follow-up. During the search for data, the family was contacted, who informed us that the patient had died after 6 months, with pneumonia recorded as the official cause of death.

In relation to the type of procedure, transfacet approaches (stage 1) were used in five cases (36\%), transpedicular (stage 2) in one case (7\%), transpedicular + partial resection of the vertebral body (stage 3 ) in four cases (29\%), costotransversectomy (stage 4) in three cases (21\%) and costotransversectomy + CAGE in one case (7\%). (Table 2) The majority of patients with lateral hernia (5/6) were treated through the transfacet approach. Of the cases of central or central-lateral hernia, all were submitted to broader decompression (stages 3 to 5). (Figure 3) The case submitted to reconstruction with CAGE (stage 5) was a revision case, with good fusion, in which a wide bilateral resection of the vertebral body was required, to push the hernia anteriorly. (Figure 4)

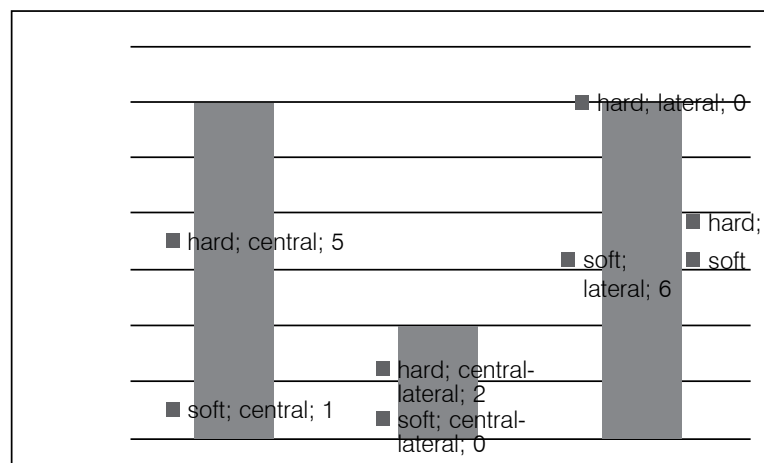

Figure 2. Association between location of the hernia and the presence or absence of calcification (hard or soft).

Table 1. Demographic data of the patients. Abbreviations: SAH (systemic arterial hypertension), DVT (deep vein thrombosis), Cl (Coronary insufficiency), COPD (chronic obstructive pulmonary disease, DM (Diabetes Mellitus).

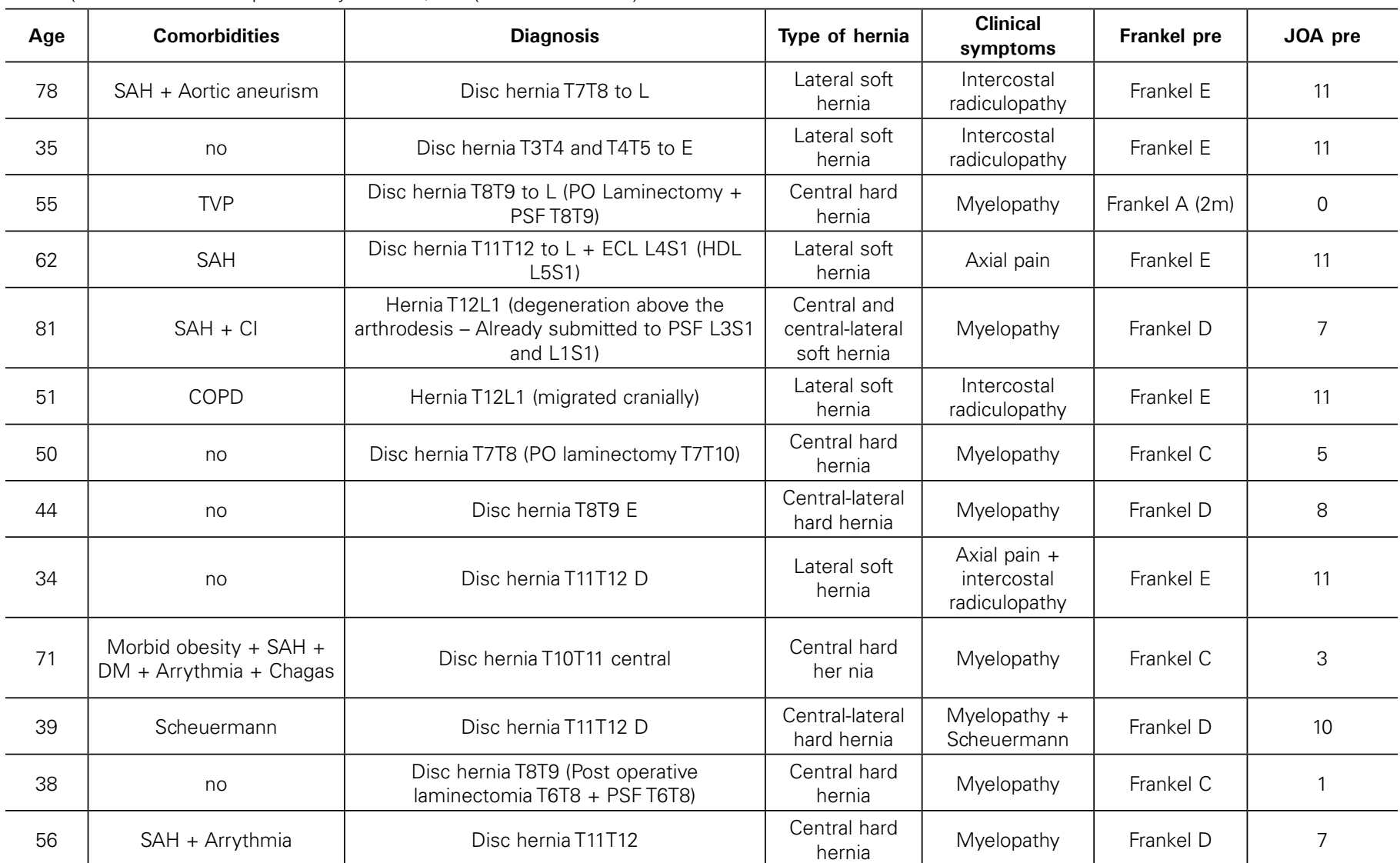

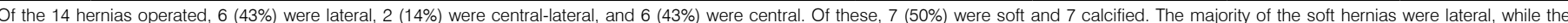
majority of the hard hernias were dural. (Figure 2). 
In four patients (five hernias), transfacet decompression was performed (stage 1). Of these five discs, arthrodesis was performed in two, who were patients who besides radicular pain, also had complaints of severe axial pain and discopathy on MRI. In the transfacet decompression, we did not perform arthrodesis (unless there was some important clinical indication, particularly axial pain with discopathy). In the other cases, we performed routine arthrodesis, as we believed that the more extensive bone decompression could lead to instability, and that arthrodesis of the thoracic spine did not present greater morbidity for the patient.

In relation to neurological symptoms, in all the cases operated on there was maintenance or improvement of the symptoms based on the Frankel scale. There were no cases of worsening of the neurological status.

Of the 13 patients operated on, eight presented myelopathy as the main symptom, while 5 presented radicular and/or axial pain that did not respond to clinical treatment or significant nerve compression, even without signs of clinical myelopathy. Of the myelopathic patients, the preoperative JOA score was 5.12 (0 to 10) and the postoperative score was 8.12 (3 to 11) $(p<0.005)$. The mean recovery rate was $66.66 \%$. (Table 3 ) Of the three patients who had reasonable rates of improvement (25\% to $49 \%$ ), two were patients who had already undergone the procedure at another service, having undergone laminectomy and evolved with major neurological deficit (Frankel neurological grades A and C) and the other was a patient with advanced myelopathy (Frankel C).

Of the 13 patients operated on, three had already been submitted to a prior procedure at another service, with laminectomy and arthrodesis. In all the cases, there was a worsening of neurological status and the hernia was not resected, requiring a new procedure for adequate decompression.

All the cases with clinical complaints of radiculopathy (three) were submitted to foraminal block at the surgical center, with the aid of fluoroscopy, achieving partial improvement for a short period of time, and subsequently underwent the definitive procedure.

Of the 13 patients, four presented major complications: one ossifying myositis of the psoas and deep vein thrombosis (DVT) in a Frankel A patient after laminectomy at another service; one postoperative infection in the lumbar region; one patient who was submitted to simultaneous decompression of the lumbar region; one death that was not related to the surgery itself, but may have been related to the underlying disease and immobility; and one patient who presented hernia and Scheuermann with worsening of the deformity, having undergone surgery five years after decompression due to progression of the kyphotic deformity (stage 3). Figure 5

Table 2. Description of the type of surgery performed in each patient, neurological status in the preoperative and postoperative stages, and complications. Abbreviations: PSF (posterior spinal fusion), R (right), L (left).

\begin{tabular}{|c|c|c|c|c|c|c|c|c|}
\hline Diagnosis & Type of hernia & Surgery & Artrodesis & Complication & $\begin{array}{c}\text { Frankel } \\
\text { pre }\end{array}$ & $\begin{array}{c}\text { Frankel } \\
\text { post }\end{array}$ & $\begin{array}{l}\text { JOA } \\
\text { pre }\end{array}$ & $\begin{array}{l}\text { JOA } \\
\text { post }\end{array}$ \\
\hline Disc hernia T7T8 to E & $\begin{array}{l}\text { Lateral } \\
\text { Soft } \\
\text { Hernia }\end{array}$ & $\begin{array}{c}\text { Discectomy T7T8 L (transfacet) } \\
\text { stage } 1\end{array}$ & No & no & Frankel E & Frankel E & 11 & 11 \\
\hline $\begin{array}{c}\text { Disc hernia T3T4 and } \\
\text { T4T5 to E }\end{array}$ & $\begin{array}{l}\text { Lateral } \\
\text { Soft } \\
\text { Hernia }\end{array}$ & $\begin{array}{l}\text { Discectomy T3T4 and } \\
\text { T4T5 L (transfacet) stage } 1\end{array}$ & No & no & Frankel E & Frankel E & 11 & 11 \\
\hline $\begin{array}{c}\text { Disc hernia T8T9 to } \\
L \text { (Post operative } \\
\text { laminectomy + PSF } \\
\text { T8T9) } \\
\end{array}$ & $\begin{array}{l}\text { Central hard } \\
\text { hernia }\end{array}$ & $\begin{array}{c}\text { Discectomy T8T9 L } \\
\text { (costotransversectomy T9) stage } \\
4\end{array}$ & $\begin{array}{l}\text { yes (PSF } \\
\text { T8T10) }\end{array}$ & $\begin{array}{l}\text { myositis } \\
\text { ossificans of the } \\
\text { psoas muscle }\end{array}$ & $\begin{array}{l}\text { Frankel A } \\
(2 \mathrm{~m})\end{array}$ & Frankel A & 0 & 3 \\
\hline $\begin{array}{l}\text { Disc hernia T11T12 to L } \\
+ \text { ECL L4S1 (HDL L5S1) }\end{array}$ & $\begin{array}{l}\text { Lateral } \\
\text { Soft } \\
\text { Hernia } \\
\end{array}$ & $\begin{array}{c}\begin{array}{c}\text { Discectomy T11T12 L (transfacet) } \\
\text { stage } 1+\text { laminectomy and PSF } \\
\text { L4S1 }\end{array} \\
\end{array}$ & $\begin{array}{l}\text { yes (PSF } \\
\text { T11T12) }\end{array}$ & $\begin{array}{l}\text { Lumbar Surgical } \\
\text { Site Infection } \\
\text { (L4S1) }\end{array}$ & Frankel E & Frankel E & 11 & 11 \\
\hline $\begin{array}{c}\text { Hernia T12L1 } \\
\text { (degeneration above } \\
\text { the area of arthrodesis } \\
\text { - already submitted to } \\
\text { PSF L3S1 and L1S1) }\end{array}$ & $\begin{array}{l}\text { Central } \\
\text { Soft hernia }\end{array}$ & $\begin{array}{c}\text { Discectomy T12L1 L } \\
\text { (transpedicular }+ \text { destruction of } \\
\text { the vertebral body stage } 3\end{array}$ & $\begin{array}{l}\text { yes (PSF } \\
\text { T12S1) }\end{array}$ & no & Frankel D & Frankel E & 7 & 10 \\
\hline $\begin{array}{c}\text { Hernia T12L1 (migrated } \\
\text { cranially) }\end{array}$ & $\begin{array}{l}\text { Lateral } \\
\text { Soft } \\
\text { Hernia } \\
\end{array}$ & $\begin{array}{l}\text { Discectomy T12L1 R } \\
\text { (transpedicular) stage } 2\end{array}$ & $\begin{array}{l}\text { yes (PSF } \\
\text { T11L1) }\end{array}$ & no & Frankel E & Frankel E & 11 & 11 \\
\hline $\begin{array}{c}\text { Disc hernia T7T8 (Post } \\
\text { operative laminectomy } \\
\text { T7T10) } \\
\end{array}$ & $\begin{array}{l}\text { Central hard } \\
\text { hernia }\end{array}$ & $\begin{array}{c}\text { Discectomy T7T8 } \\
\text { (costotransversectomy + CAGE) } \\
\text { stage } 5 \\
\end{array}$ & $\begin{array}{l}\text { yes (PSF } \\
\text { T6T10) }\end{array}$ & no & Frankel C & Frankel D & 5 & 9 \\
\hline Disc hernia T8T9 E & $\begin{array}{l}\text { Central-lateral } \\
\text { hard hernia }\end{array}$ & $\begin{array}{c}\text { Discectomy T8T9 (transpedicular } \\
+ \text { destruction of the vertebral } \\
\text { body) stage } 3\end{array}$ & $\begin{array}{l}\text { yes (PSF } \\
\text { T7T10) }\end{array}$ & no & Frankel D & Frankel E & 8 & 11 \\
\hline Disc hernia T11T12 D & $\begin{array}{l}\text { Lateral soft } \\
\text { hernia }\end{array}$ & \begin{tabular}{|c|} 
Discectomy T11T12 R (transfacet) \\
stage 1 \\
\end{tabular} & $\begin{array}{l}\text { yes (PSF } \\
\text { TT11L1) }\end{array}$ & no & Frankel E & Frankel E & 11 & 11 \\
\hline $\begin{array}{c}\text { Disc hernia T10T11 } \\
\text { central }\end{array}$ & $\begin{array}{l}\text { Central hard } \\
\text { hernia }\end{array}$ & $\begin{array}{c}\text { Discectomy T10T11 } \\
\text { (transpedicular }+ \text { destruction of } \\
\text { the vertebral body) stage } 3\end{array}$ & $\begin{array}{l}\text { yes (PSF } \\
\text { T8L1) }\end{array}$ & $\begin{array}{l}\text { died after } 6 \\
\text { weeks }\end{array}$ & Frankel C & Frankel D & 3 & 5 \\
\hline Disc hernia T11T12 D & $\begin{array}{l}\text { Central-lateral } \\
\text { hard hernia }\end{array}$ & $\begin{array}{c}\text { Discectomy T11T12 } \\
\text { (transpedicular }+ \text { destruction of } \\
\text { the vertebral body) stage } 3 \\
\end{array}$ & $\begin{array}{l}\text { yes (PSF } \\
\text { T11T12) }\end{array}$ & no & Frankel D & Frankel E & 10 & 11 \\
\hline $\begin{array}{l}\text { Disc hernia T8T9 (Post } \\
\text { operative laminectomy } \\
\text { T6T8 + PSF T6T8) }\end{array}$ & $\begin{array}{l}\text { Central hard } \\
\text { hernia }\end{array}$ & $\begin{array}{c}\text { Discectomy T7T8 (transpedicular } \\
\text { + bilateral destruction of the } \\
\text { vertebral body) stage } 3\end{array}$ & $\begin{array}{l}\text { yes (PSF } \\
\text { T6T10) }\end{array}$ & no & Frankel C & Frankel C & 1 & 5 \\
\hline Disc hernia T11T12 & $\begin{array}{l}\text { Central hard } \\
\text { hernia }\end{array}$ & $\begin{array}{c}\text { Discectomy T11T12 } \\
\text { (costotransversectomy) } \\
\text { stage } 4\end{array}$ & $\begin{array}{l}\text { yes (PSF } \\
\text { T10L1) }\end{array}$ & no & Frankel D & Frankel D & 7 & 11 \\
\hline
\end{tabular}




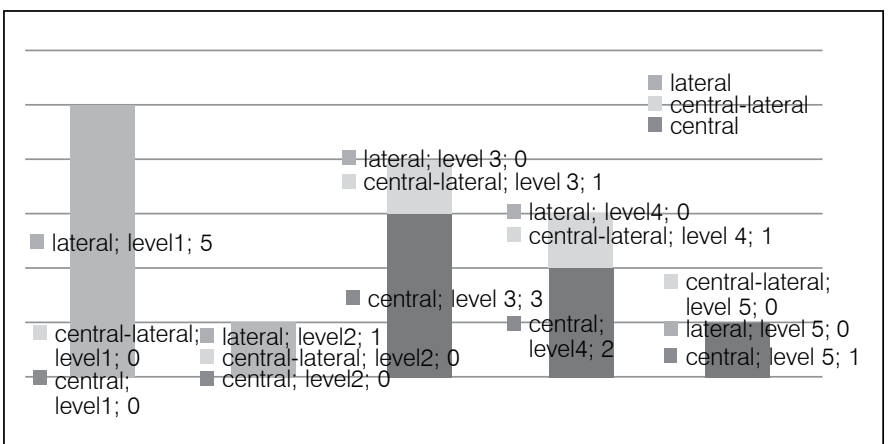

Figure 3. Association between location of the hernia and type of decompression performed.

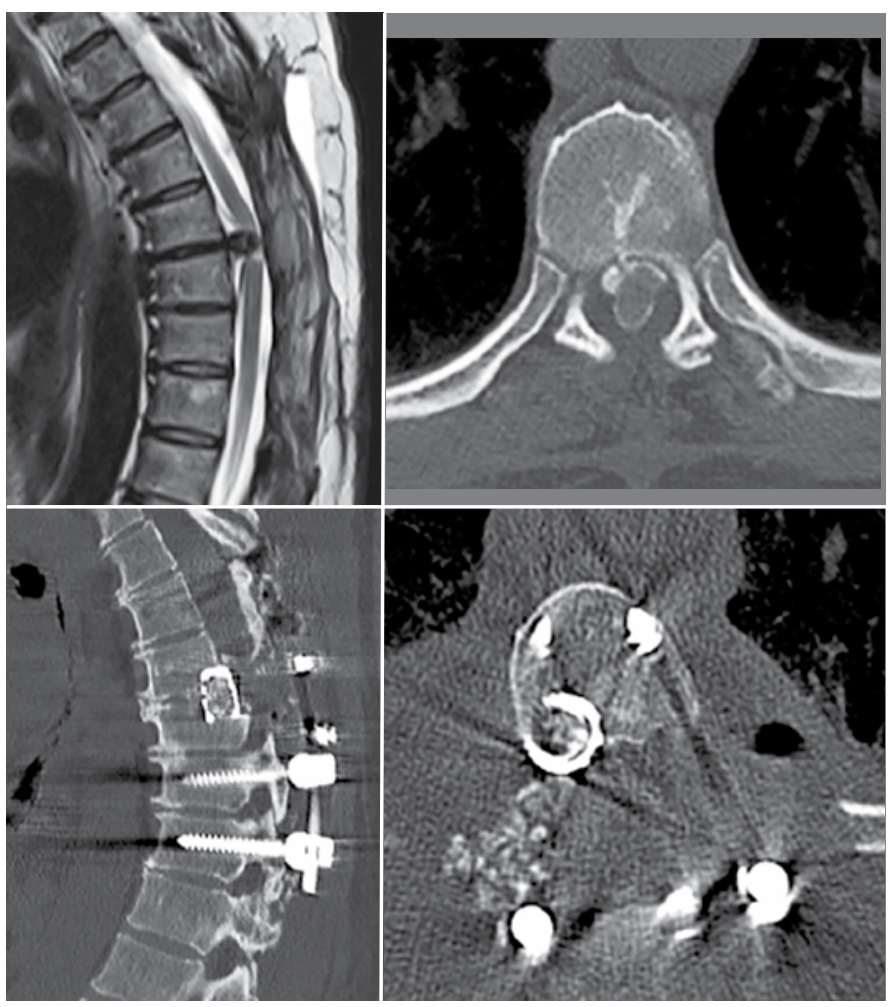

Figure 4. Case AMC. Patient submitted to two prior procedures at another service with laminectomy, when they presented worsening of the neurological status (Frankel C). Patient was a Jehovah's Witness. Submitted to decompression through costotransversectomy + CAGE. Postoperative neurological status Frankel D.

Table 3. Neurological status of the patients with myelopathy. Abbreviations: JOA (Japanese Orthopaedic Association) modified for thoracic myelopathy

\begin{tabular}{c|c|c|c}
\hline JOA pre & JOA post & Recovery rate & Column1 \\
\hline 0 & 3 & $27.27 \%$ & reasonable \\
\hline 7 & 10 & $75 \%$ & excellent \\
\hline 5 & 9 & $66 \%$ & good \\
\hline 8 & 11 & $100 \%$ & excellent \\
\hline 3 & 5 & $25 \%$ & reasonable \\
\hline 10 & 11 & $100 \%$ & excellent \\
\hline 1 & 5 & $40 \%$ & reasonable \\
\hline 7 & 11 & $100 \%$ & excellent \\
\hline 5.125 & 8.125 & $66.66 \%$ & \\
\hline
\end{tabular}

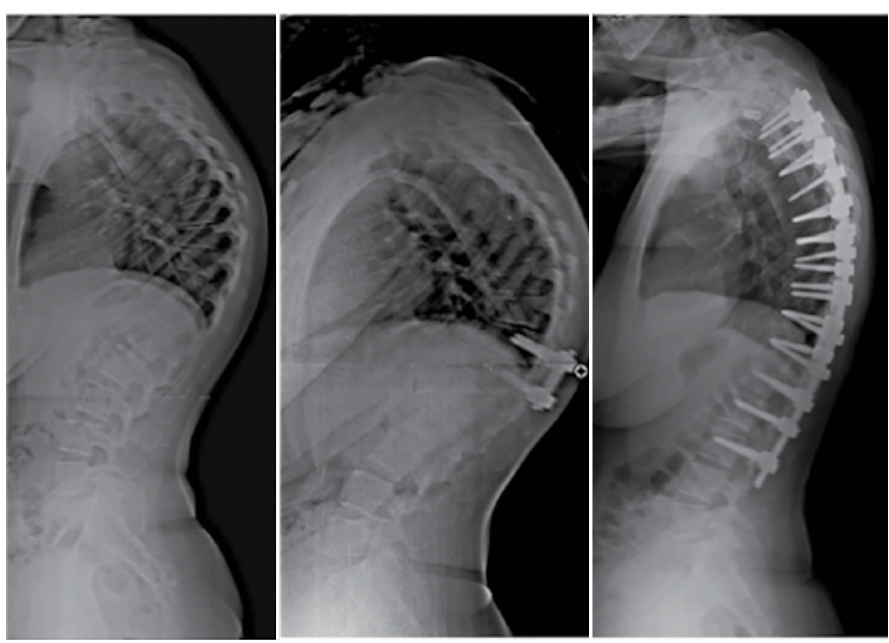

Figure 5. Patient with central-lateral, calcified hernia of T11T12 with myelopathy and Scheuermann, submitted to stage 3 decompression. Neurological improvement was obtained (Frankel R to E); however, the deformity worsened; the patient began to present pain, and was therefore submitted to correction with osteotomies by the Ponte technique, and arthrodesis of T3 to L3.

\section{DISCUSSION}

The treatment of thoracic disc hernia is highly controversial. Initial attempts at decompression through isolated laminectomy led to results that were far short of the ideal, with rates of paraparesis and paraplegia of around $24 \%$ to $45 \%$ of cases. ${ }^{7,8}$ These catastrophic results led to the anterior approach becoming the gold standard in the treatment of this pathology. ${ }^{8}$ However, in recent years, with the description of posterior-lateral approaches, the posterior approach has regained popularity, not only in the treatment of degenerative diseases, but also of tumors, trauma and deformities. ${ }^{5,6,10}$

The transfacet posterior approach was first described by Stillerman $^{13}$ and is considered a very good option for the treatment of soft lateral disc hernias. However, for cases of more central, or calcified hernias, this approach is often inadequate, as it does not allow for medical movement of the instruments and exploration of the region anterior to the dura-mater. More lateral resections are therefore necessary, such as transpedicular approaches and costotransversectomy. $4,7,8,10,14-16$

Although it is an uncommon disorder, various authors have demonstrated results with one or other technique,,$^{3,4,7,10,13-16}$ but nearly always treating all the cases with the same approach., ${ }^{3,13-16}$ We believe that the majority of thoracic disc hernias can be treated by the posterior approach with good safety; however, when the hernia is located more centrally, and is more calcified, the bone resection must be performed more laterally to enable exploration anterior to the dura-mater, without mobilizing the neurological structures. We therefore describe our approach, with à la carte decompression, in an analogy with peritalar release in the treatment of congenital clubfoot. ${ }^{11}$

Börm et al. also presented their results with various types of decompression, depending on the type of hernia. They studied 28 disc hernias, of which eight were submitted to costotransversectomy, one to lateral extracavitary decompression, two to foraminotomy, 15 to the transfacet or transpedicular approaches, and two to the translaminar approach. Analyzing the cases by location of the hernia, we have: of the five lateral hernias, two were submitted to transfacet-transpedicular decompression, two to foraminotomy, and one by the interlaminar approach. Of the 21 cases of paramedian hernia, twelve were submitted to transfacet-transpedicular decompression, seven to costotransversectomy, one by the extracavitary lateral route, and one by the interlaminar route. Of the two cases of central hernia, one was submitted to costotransversectomy and one to the transfacet-transpedicular approach. Compared with our results, we treated the majority of cases of lateral hernias $(5 / 6)$ by the transfacet approach, and the central and central-lateral hernias 
(8 cases) always with a broader approach. In our study, we had a far higher proportion of central hernias than that found by this author, which we believe may be due to a difference in the classification system used. We therefore classified the hernias based on their position in relation to the spinal cord. In regard to neurological improvement, this author showed a rate of neurological recovery, based on the JOA scale, of $39.5 \%$, with patients who presented more advanced initial impairment presenting poorer results. In our case series, we obtained a recovery rate of $66.66 \%$, also with poor results in those patients who presented higher impairment (particular patients submitted to prior laminectomy at another service).

Stillerman ${ }^{4}$ also presented the result of 82 patients treated, including a flow chart to define the best approach to these cases. In his case series, 49 patients were submitted to transthoracic decompression, eight to extracavitary lateral decompression, two to transpedicular decompression, and 23 to transfacet decompression. However, in that same study, he demonstrates an increasing trend to treat this disease by the posterior approach, with the transfacet approach being performed in $70 \%$ of cases in the last six years of the study.

In our case series, a novel characteristic is the high number of revision cases (3/12), in which decompression by laminectomy had been performed previously in other services. In all the cases, there was worsening of the neurological deficit with this surgery. Thus, although there is plenty of data in the literature showing poor results with isolated laminectomy, ${ }^{7,8}$ this practice was not abolished in our service, further increasing the importance of this study, in order to clarify and add information about the subject.
When we compare the patients with calcified and non-calcified hernias (hard vs. soft), despite the very small number, we did not find any significant differences. This is similar to another study that also made this comparison. ${ }^{10}$ However, we have the clinical impression that in the presence of more calcified hernia, there is greater technical difficulty at the time of surgical resection, and a more lateral approach may be necessary to achieve the resection without manipulating the neurological elements.

In terms of complications, we had four, but these were not related to the surgery itself. In all cases, we achieved improvement or maintenance of the neurological symptoms, according to the Frankel and JOA scales, without any case of worsening

\section{CONCLUSION}

The treatment of thoracic disc herniation can be done effectively and safely by the posterior approach, but it is important to select the best approach, based on the location of the hernia, whether it is hard or soft, and according to the surgeon's experience.

The approach may be transfacet, transpedicular, transpedicular with partial resection of the vertebral body, costotransversectomy or costotransversectomy + reconstruction with CAGE, which depending on the location of the hernia, allows the surgeon to access the region anterior to the dura mater, without manipulating the neurological structures.

All the authors declare that there are no conflicts of interest regarding this article.

CONTRIBUTIONS OF THE AUTHORS: Each author made significant individual contributions to the development of the manuscript. MTD was the main surgeon and conceiver of the study. SD is the senior physician of the group and assisted in the idea and idealization of the surgical technique, as well as in writing the manuscript. PFJ and APE assisted in the surgeries and contributed to the planning of the work. BCRA is the monitor of the group's study center, and assisted in the bibliographic review. ALPC and WEPJ were part of one of the centers where the study was performed, and contributed to some of the cases.

\section{REFERENCES}

1. Yoshihara H. Surgical treatment for thoracic disc herniation: an update. Spine (Phila Pa 1976). 2014;39(6):E406-12.

2. Yoshihara H, Yoneoka D. Comparison of in-hospital morbidity and mortality rates between anterior and nonanterior approach procedures for thoracic disc herniation. Spine (Phila Pa 1976). 2014;39(12):E728-33.

3. Arce CA, Dohrmann GJ. Herniated thoracic disks. Neurol Clin. 1985;3(2):383-92.

4. Stillerman CB, Chen TC, Couldwell WT, Zhang W, Weiss MH. Experience in the surgical management of 82 symptomatic herniated thoracic discs and review of the literature. J Neurosurg. 1998;88(4):623-33.

5. Lee SS, Lenke LG, KukloTR, Valenté L, Bridwell KH, Sides B, et al. Comparison of Scheuermann kyphosis correction by posterior-only thoracic pedicle screw fixation versus combined anterior/posterior fusion. Spine (Phila Pa 1976). 2006;31(20):2316-21.

6. Tomita K, Kawahara N, Baba H, Tsuchiya H, Fujita T, Toribatake Y. Total em bloc spondylectomy. A new surgical technique for primary malignant vertebral tumors. Spine (Phila Pa 1976). 1997;22(3):324-33.

7. Patterson $\mathrm{RH} J \mathrm{~J}$, Arbit E. A surgical approach through the pedicle to protruded thoracic discs. J Neurosurg. 1978:48(5):768-72.

8. Bransford R, Zhang F, Bellabarba C, Konodi M, Chapman JR. Early experience treating thoracic disc herniations using a modified transfacet pedicle-sparing decompression and fusion. J Neurosurg Spine. 2010;12(2):221-31.

9. Black P. Laminotomy/medial facet approach in the excision of thoracic disc herniation. Neurosurg Focus. 2000;9(4):e6.

10. Börm W, Bäzner U, König RW, Kretschmer T, Antoniadis G, Kandenwein J. Surgical treatment of thoracic disc herniations via tailored posterior approaches. Eur Spine J. 2011;20(10):1684-90.

11. Bensahel H, Csukonyi Z, Desgrippes Y, Chaumien JP. Surgery in residual clubfoot: one-stage medioposterior release "à la carte". J Pediatr Orthop. 1987·7(2):145-8. 12. Arnold PM, Johnson PL, Anderson KK. Surgical management of multiple thoracic disc herniations via a transfacet approach: a report of 15 cases. J Neurosurg Spine. 2011:15(1):76-81.

13. Stillerman CB, Chen TC, Day JD, Couldwell WT, Weiss MH. The transfacet pedicle-sparing approach for thoracic disc removal: cadaveric morphometric analysis and preliminary clinical experience. J Neurosurg. 1995:83(6):971-6.

14. Bilsky MH. Transpedicular approach for thoracic disc herniations. Neurosurg Focus. 2000;9(4):e3

15. Liu N, Chen Z, Qi Q, Li W, Guo Z. Circumspinal decompression and fusion through a posterior midline incision to treat central calcified thoracolumbar disc herniation: a minimal 2-year follow-up study with reconstruction CT. Eur Spine J. 2014;23(2):373-81.

16. Kim KD, Babbitz JD, Mimbs J. Imaging-guided costotransversectomy for thoracic disc herniation. Neurosurg Focus. 2000:9(4):e7.

17. Frankel HL, Hancock DO, Hyslop G, Melzak J, Michaelis LS, Ungar GH, et al. The value of postural reduction in the initial management of closed injuries of the spine with paraplegia and tetraplegia. I. Paraplegia. 1969:7(3):179-92.

18. Yamasaki R, Okuda S, Maeno T, Haku T, Iwasaki M, Oda T. Surgical outcomes of posterior thoracic interbody fusion for thoracic disc herniations. Eur Spine J. 2013:22(11):2496-503.

19. Hirabayashi K, Miyakawa J, Satomi K, Maruyama T, Wakano K. Operative results and postoperative progression of ossification among patients with ossification of cervical posterior longitudinal ligament. Spine (Phila Pa 1976). 1981;6(4):354-64.

20. Ohnishi K, Miyamoto K, KanamoriY, Kodama H, Hosoe H, Shimizu K. Anterior decompression and fusion for multiple thoracic disc herniation. J Bone Joint Surg Br. 2005;87(3):356-60 